\title{
BADANIE ZUŻYCIA ENERGII PRZEZ SAMOCHÓD ELEKTRYCZNY
}

\author{
ZDZISŁAW CHŁOPEK ${ }^{2}$ \\ Instytut Transportu Samochodowego w Warszawie
}

\section{Streszczenie}

W ostatnich latach następuje dynamiczny rozwój napędów elektrycznych w motoryzacji. Jest to podyktowane przede wszystkim względami ekologicznymi, m.in. emisją zanieczyszczeń i hałasu oraz wyczerpywaniem się zasobów naturalnych surowców do wytwarzania paliw ciekłych i gazowych. W celu oceny energetycznych właściwości samochodów elektrycznych jest konieczne badanie zużycia energii przez pojazdy w warunkach odpowiadających rzeczywistemu użytkowaniu. W pracy zaproponowano formalny opis właściwości energetycznych i ekonomicznych samochodów elektrycznych. Wprowadzono pojęcia sprawności napędu, ładowania akumulatorów, odzyskiwania energii hamowania i ogólnej oraz drogowego zużycia energii dla samochodów z układami bez odzyskiwania i z odzyskiwaniem energii hamowania.

Przedstawiono wyniki badań samochodu elektrycznego Zilent Courant w warunkach symulujących użytkowanie w mieście. Jest to samochód bez układu odzyskiwania energii w czasie hamowania. Badania przeprowadzono na hamowni podwoziowej w testach UDC (Urban Drivig Cycle), FTP-75 (Federal Transient Procedure) i Stop and Go do symulacji jazdy w zatorach ulicznych. Wyznaczono średnie drogowe zużycie energii oraz sprawność ogólną pojazdu w testach. Badano również drogowe zużycie energii w wyróżnionych warunkach dynamicznych pracy samochodu - wyznaczono średnie drogowe zużycie energii w stanach dodatniego i ujemnego przyspieszenia.

Słowa kluczowe: samochód elektryczny, zużycie energii.

\section{Wprowadzenie}

Idea pojazdów napędzanych silnikami elektrycznymi jest bardzo stara. Pierwsze samochody elektryczne powstały już w latach trzydziestych XIX w. Prototypowe pojazdy elektryczne zbudowali m.in.: Szkot Robert Anderson, Holender Sibrandus Stratingh Groningen oraz Amerykanin Thomas Davenport [22]. W 1890 r. w Stanach Zjednoczonych Ameryki rozpoczęto masową produkcję samochodów elektrycznych. Największy udział pojazdów z napędami elektrycznymi był na początku XX w. - w 1912 r. w Stanach Zjednoczonych

Ameryki było eksploatowanych ponad 20000 samochodów elektrycznych. Po I wojnie światowej nastąpiło wypieranie samochodów elektrycznych przez samochody napędzane

${ }^{1}$ Instytut Transportu Samochodowego, ul. Jagiellońska 80, 03-301 Warszawa, e-mail: zdzisław.chlopek@its.waw.pl,

tel.: 224385126 
silnikami spalinowymi przede wszystkim ze względu na większą moc użyteczną silników spalinowych oraz lepsze właściwości eksploatacyjne tych pojazdów, m.in. zdecydowanie większy zasięg.

W ostatnich latach w rozwoju samochodów elektrycznych upatruje się możliwości rozwiązania poważnych problemów ekologicznych motoryzacji, związanych m.in. z emisją zanieczyszczeń i hałasu, a także z wyczerpywaniem się zasobów naturalnych, przede wszystkim surowców do wytwarzania paliw ciekłych i gazowych $[1,6,9,16]$.

Ocena emisji zanieczyszczeń oraz zużycia energii dla samochodów elektrycznych w celu porównania z klasycznymi rozwiązaniami motoryzacyjnymi jest sprawa złożoną. Wynika to z faktu, że w znacznej mierze obciążenie środowiska jest w przypadku samochodów elektrycznych przeniesione na etap wytwarzania energii elektrycznej. Możliwym rozwiązaniem tego problemu jest dokonywanie tzw. analizy Well-to-Whell - od źródła nośników energii do kół pojazdu [1, 8, 9, 12, 14, 17, 26]. Analiza ta umożliwia ocenę emisji zanieczyszczeń w całym cyklu wytwarzania nośników energii oraz ich wykorzystywania do napędu pojazdu. Zgodnie z tą analizą można również ocenić wrażliwość całkowitej szkodliwości ocenianych rozwiązań na technologię przetwarzania nośników energii - w istocie wrażliwość to jest bardzo duża i w znacznym stopniu może być decydująca o ekologicznej ocenie porównywanych rozwiązań. W przypadku samochodów elektrycznych szczególnie ważny jest problem wytwarzania produkcji elektrycznej $[1,7-9,13,15,17,20,25]$ - w przeważającej mierze energia elektryczna jest wytwarzana - przynajmniej w Polsce - z kopalnych nośników energii (przede wszystkim z węgla kamiennego) z wykorzystaniem technologii dalekich od poszanowania środowiska. Mimo tych zastrzeżeń należy jednak zwrócić uwagę na ważny argument, przemawiający za rozwojem napędów elektrycznych. Nawet w przypadku negatywnej oceny emisji zanieczyszczeń w analizie Well-to-Whell, w przypadku pojazdów z napędami elektrycznymi istnieje możliwość „przesunięcia" miejsc źródeł emisji zanieczyszczeń z obszarów największych zagrożeń - z centrów wielkich aglomeracji miejskich do miejsc położenia elektrowni $[1,10,13,20]$.

Badania zużycia energii i emisji zanieczyszczeń w związku z eksploatacją samochodów elektrycznych mają bogatą literaturę, m.in. $[1,3,7-17,20-26]$. Analizy są prowadzone zazwyczaj dla warunków badań homologacyjnych. W pracy [12] przeprowadzono analizę porównawczą zużycia energii i emisji gazów cieplarnianych w cyklu Well-to-Whell z rozdziałem na fazy: Well-to-Tank (od źródła nośnika energii do zbiornika energii) i Tankto-Whell (od zbiornika energii do kół napędowych pojazdu) dla: samochodu z silnikiem o zapłonie iskrowym, samochodu z silnikiem o zapłonie samoczynnym, samochodu hybrydowego niedoładowywanego ze źródeł zewnętrznych (NOVC - Not Off-Vehicle Charging, HEV - Hybrid Electric Vehicle [27]), samochodu hybrydowego doładowywanego ze źródeł zewnętrznych (OVC - Off-Vehicle Charging, PHEV - Plug-In Hybrid Electric Vehicle [27]), samochodu elektrycznego (BEV - Battery Electric Vehicle [12]) i samochodu z ogniwem paliwowym (FCV - Fuel Cell Vehicle [12]). Najlepsze wyniki uzyskano dla samochodów hybrydowych oraz samochodu z ogniwem paliwowym. Dla samochodów elektrycznych decydująca o gorszych wynikach jest faza wytwarzania energii elektrycznej - energochłonna i będąca źródłem dużej emisji gazów cieplarnianych w związku z powszechnym stosowaniem technologii z użyciem surowców kopalnych. Wiele prac zawiera analityczne rozważania na temat pozytywnych i negatywnych aspektów wytwarzania, eksploa- 
tacji samochodów elektrycznych, a także zagospodarowywania zużytych pojazdów $[1,7$, $13-15,17,20,25,26]$.

Wbrew obiegowym opiniom, rozpowszechnianym przez populistyczne źródła, samochody elektryczne nie są na razie realną konkurencją dla pojazdów napędzanych silnikami spalinowymi. Za najbardziej obiecujące rozwiązanie należy obecnie raczej traktować pojazdy z napędami hybrydowymi - elektryczno-spalinowymi [9, 10-12, 14, 19]. Z technicznego punktu widzenia należy ocenić, że we współczesnych pojazdach elektrycznych najsłabszym elementem są akumulatory energii elektrycznej $[1,8,14,15]$. Nie jest to $w$ żadnym przypadku zaskoczeniem, gdyż powszechnie wiadomo, że magazynowanie energii jest szczególnie trudnym problemem - do tej pory niedoścignionym rozwiązaniem jest stosowanie paliw ciekłych $[12,14]$.

To ostrożne podejście do problemu pojazdów elektrycznych nie jest w żadnej sprzeczności z faktem dynamicznie prowadzonych prac nad rozwojem napędów elektrycznych nie tylko w małych samochodach osobowych, ale i autobusach, samochodach ciężarowych $[1,9,25]$ oraz pojazdach jednośladowych $[3,23,24]$.

W niniejszej pracy zajęto się problemem zużycia energii przez samochód elektryczny w warunkach jego typowego użytkowania [21]. Przyjmuje się, że podstawowe zastosowanie samochodów elektrycznych jest obecnie związane $z$ ich użytkowaniem w warunkach ruchu w centrach miejskich. W związku z tym przeprowadzono badania w testach homologacyjnych, symulujących warunki miejskie i podmiejskie: europejskim UDC (Urban Driving Cycle - miejski test jezdny) i amerykańskim FTP-75 (Federal Transient Procedure - federalna procedura przejściowa) [27]. Dodatkowo przeprowadzono badania w teście Stop and Go $[2,5]$ do symulacji ruchu pojazdów w warunkach zatorów drogowych.

\section{Opis właściwości energetycznych i ekonomicznych samochodów elektrycznych}

Do opisu właściwości energetycznych i ekonomicznych samochodów elektrycznych stosuje się pojęcia charakteryzujące sprawność i zużycie energii.

Dla samochodu elektrycznego bez odzyskiwania energii hamowania system sprawności definiuje się w następujący sposób:

- sprawność napędu

$$
\eta_{D}=\frac{N_{R}}{N_{T}}
$$

- sprawność ładowania akumulatorów

$$
\eta_{\mathrm{CH}}=\frac{\mathrm{N}_{\mathrm{T}}}{\mathrm{N}_{\mathrm{CH}}}
$$

- sprawność ogólna

$$
\eta_{\mathrm{G}}=\eta_{\mathrm{CH}} \cdot \eta_{\mathrm{D}}
$$


gdzie:

$\mathrm{N}_{\mathrm{T}}$ - moc elektrycznego napędu samochodu,

$\mathrm{N}_{\mathrm{R}}-$ moc oporów jazdy,

$\mathrm{N}_{\mathrm{CH}}$ - moc ładowania akumulatorów.

Dla samochodu elektrycznego z odzyskiwaniem energii hamowania system sprawności jest zdefiniowany w następujący sposób:

- sprawność napędu

$$
\eta_{D}=\frac{N_{R}}{N_{T}-N_{U}}
$$

- sprawność odzyskiwania energii hamowania

$$
\eta_{\mathrm{U}}=\frac{\mathrm{N}_{\mathrm{U}}}{\mathrm{N}_{\mathrm{B}}}
$$

gdzie:

$\mathrm{N}_{\mathrm{B}}$ - moc hamowania maszyną elektryczną,

$\mathrm{N}_{\mathrm{U}}-$ moc odzyskiwania energii hamowania.

Drogowe zużycie energii definiuje się jako pochodną zużywanej energii względem drogi przebywanej przez pojazd. Dla samochodu elektrycznego bez odzyskiwania energii hamowania drogowe zużycie energii wynosi:

$$
\mathrm{c}=\frac{\mathrm{dL}_{\mathrm{T}}(\mathrm{s})}{\mathrm{ds}}
$$

gdzie:

$$
\begin{aligned}
& \mathrm{S} \text { - droga przebywana przez pojazd, } \\
& \mathrm{L}_{\mathrm{T}(\mathrm{s})} \text { - praca elektrycznego napędu samochodu jako funkcja drogi.. }
\end{aligned}
$$

Dla samochodu elektrycznego z odzyskiwaniem energii hamowania drogowe zużycie energii wynosi:

$$
\mathrm{c}=\frac{\mathrm{d}\left(\mathrm{L}_{\mathrm{T}}(\mathrm{s})-\mathrm{L}_{\mathrm{U}}(\mathrm{s})\right)}{\mathrm{ds}}
$$

gdzie:

$\mathrm{L}_{\mathrm{U}(\mathrm{s})}$ - odzyskiwana energii hamowania jako funkcja drogi.

Na rysunku 1 przedstawiono schemat przepływu mocy w zespole napędowym ${ }^{2}$ samochodu elektrycznego z odzyskiwaniem energii elektrycznej.

W odzyskiwaniu energii hamowania kluczową rolę odgrywa sprawność odzyskiwania energii hamowania. W warunkach użytkowania pojazdów w miastach występują często fazy przyspieszania i hamowania, zatem energia hamowania stanowi znaczącą pozycję w bilansie energetycznym. Problemem jest sprawność odzyskiwania energii hamowania, często niewielka $[8,12,15,21]$.

\footnotetext{
${ }^{2}$ Termin „układ napędowy" jest używany - zgodnie z tradycyjnym stosowaniem w naukach motoryzacyjnych - do oznaczenia układu przenoszenia energii mechanicznej z silnika do kół jezdnych pojazdu. Dla układu napędowego wraz z silnikiem oraz zbiornikiem energii stosuje się w niniejszej pracy termin „zespół napędowy".
} 


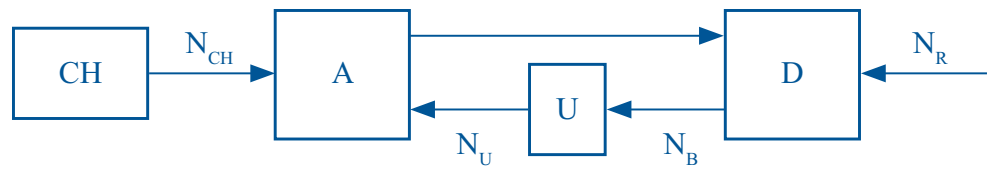

Rys. 1. Schemat przepływu mocy w zespole napędowym samochodu elektrycznego z odzyskiwaniem energii elektrycznej. Oznaczenia: CH - układ ładowania akumulatora, A - akumulator, D - układ napędowy samochodu, $\mathrm{U}$ - układ odzyskiwania energii hamowania, $\mathrm{N}_{\mathrm{CH}}$ - ładowania akumulatorów,

$\mathrm{N}_{\mathrm{T}}$ - moc elektrycznego napędu samochodu, $\mathrm{N}_{\mathrm{R}}$ - moc oporów jazdy, $\mathrm{N}_{\mathrm{B}}-$ moc hamowania maszyną elektryczną, $\mathrm{N}_{\mathrm{U}}$ - moc odzyskiwania energii hamowania

\section{Badania empiryczne zużycia energii przez samochód elektryczny}

Badania empiryczne zużycia energii przez samochód elektryczny przeprowadzono na hamowni podwoziowej w Centrum Ochrony Środowiska w Instytucie Transportu Samochodowego [4]. Obiektem badań był elektryczny samochód osobowy Zilent Courant wyprodukowany w Chińskiej Republice Ludowej. Jest to - zgodnie z punktem 2 Regulaminu 101 EKG ONZ - tzw. „pure electric vehicle”, czyli samochód z zasilaniem silników elektrycznych wyłącznie $z$ akumulatorów energii elektrycznej. Samochód Zilent Courant ma układ napędowy bez odzyskiwania energii hamowania.

W tabeli 1 przedstawiono podstawowe dane samochodu Zilent Courant.

Tab. 1. Dane elektrycznego samochodu osobowego marki Zilent model Courant

\begin{tabular}{|l|c|c|}
\hline \multicolumn{1}{|c|}{ Nazwa } & Dane & Jednostka miar \\
\hline Wymiary & $3618 \times 1563 \times 1533$ & $\mathrm{~mm}$ \\
\hline Masa pojazdu gotowego do jazdy & 1170 & $\mathrm{~kg}$ \\
\hline Liczba pasażerów & 4 & $\mathrm{~km} / \mathrm{h}$ \\
\hline Prędkość maksymalna & 85 & $\mathrm{~km} / \mathrm{h}$ \\
\hline Prędkość ekonomiczna & 40 & \\
\hline Zdolność pokonywania wzniesień & $36 \%\left(20^{\circ}\right)$ & \\
\hline Zasięg przy prędkości ekonomicznej & $>150 \mathrm{~km}$ & \\
\hline Moc znamionowa silnika elektrycznego & $8,5 \mathrm{~kW}$ & \\
\hline Napięcie znamionowe akumulatorów & 120 & \\
\hline Typ akumulatorów & $120 \mathrm{~V}$ & \\
\hline System ładowania akumulatorów & $\begin{array}{c}\text { Ah akumulatorów } 12 \mathrm{~V} / 100 \\
\text { Kwasowo-ołowiowe } \\
\text { Bezobsługowe }\end{array}$ & \\
\hline Czas ładowania akumulatorów & $\begin{array}{c}\text { Zasilanie zewnętrzne } \\
(220-230) \mathrm{V} /(50-60) \mathrm{Hz} ; \\
\text { moc 1,5 kW }\end{array}$ & \\
\hline Czas ładowania akumulatorów & $(12-14) \mathrm{h}$ & \\
\hline
\end{tabular}




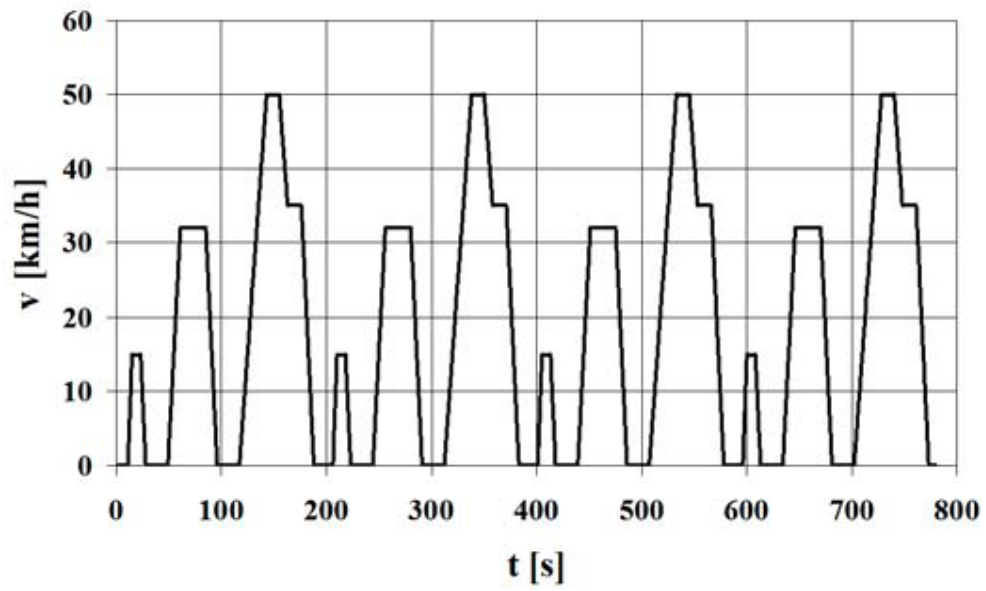

Rys. 2. Test UDC

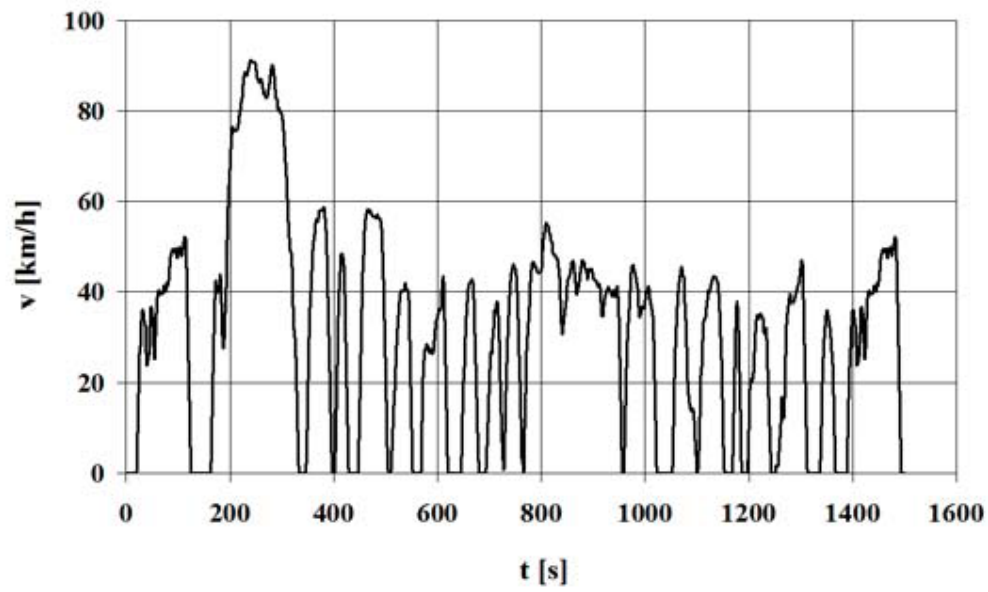

Rys. 3. Test FTP-75

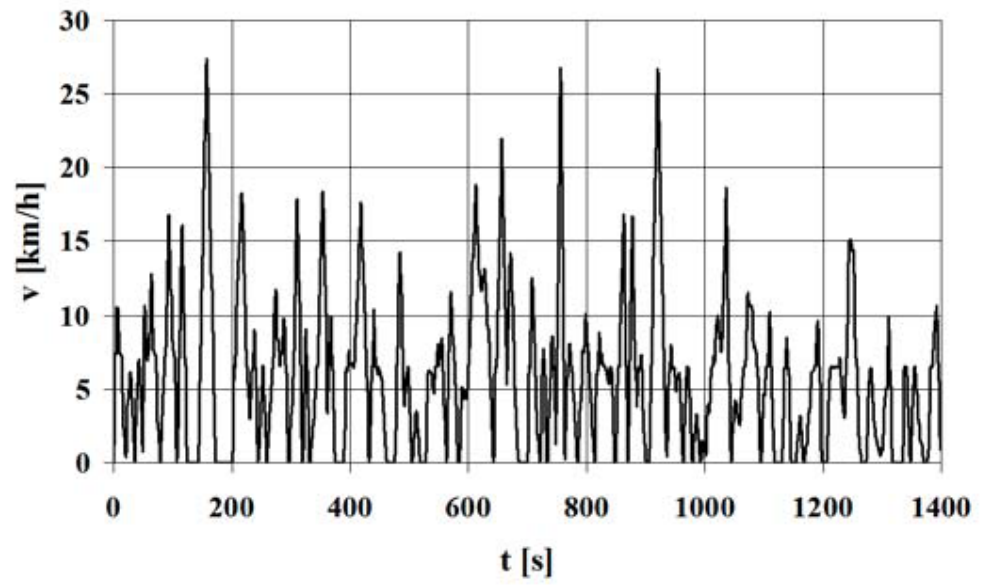

Rys. 4. Test Stop And Go 
TDo symulacji warunków ruchu w miastach wybrano dwa testy homologacyjne [27]: europejski - UDC (Urban Driving Cycle - miejski test jezdny) - rysunek 2 oraz amerykański - FTP-75 (Federal Transient Procedure - federalny test przejściowy) - rysunek 3, a także test specjalny Stop and Go do symulacji jazdy w warunkach zatorów ulicznych $[2,5]$ - rysunek 4.

Badania przeprowadzono na jednorolkowej hamowni podwoziowej z regulowaną charakterystyką oporów firmy AVL-Zoellner [3].

W czasie badań na hamowni podwoziowej dokonywano pomiarów:

- prędkości jazdy samochodu na rolce hamowni podwoziowej,

- napięcia na zespole akumulatorów,

- natężenia prądu w instalacji napędowej pojazdu.

Charakterystykę mocy pochłanianej przez hamownię podwoziową zidentyfikowano na podstawie badań empirycznych wybiegu samochodu [4].

Rejestracji sygnałów badanych wielkości dokonywano z czasem próbkowania $1 \mathrm{~s}$. Zarejestrowane sygnały zostały poddane wstępnemu przetwarzaniu w celu usunięcia błędów grubych i zmniejszenia udziału szumów o wysokich częstotliwościach. Do poszukiwania błędów grubych wykorzystano analizę bieżącej wariancji sygnałów. W celu zmniejszenia udziału szumów o wysokich częstotliwościach w sygnałach zastosowano filtracje dolnoprzepustową. Wykorzystano do tego celu filtr Golaya-Savitzky'ego [18] z wielomianem drugiego stopnia oraz z aproksymacją obustronną po 2 punkty.

Na rysunkach 5-7 przedstawiono przykładowo wyniki badań w teście Stop and Go.

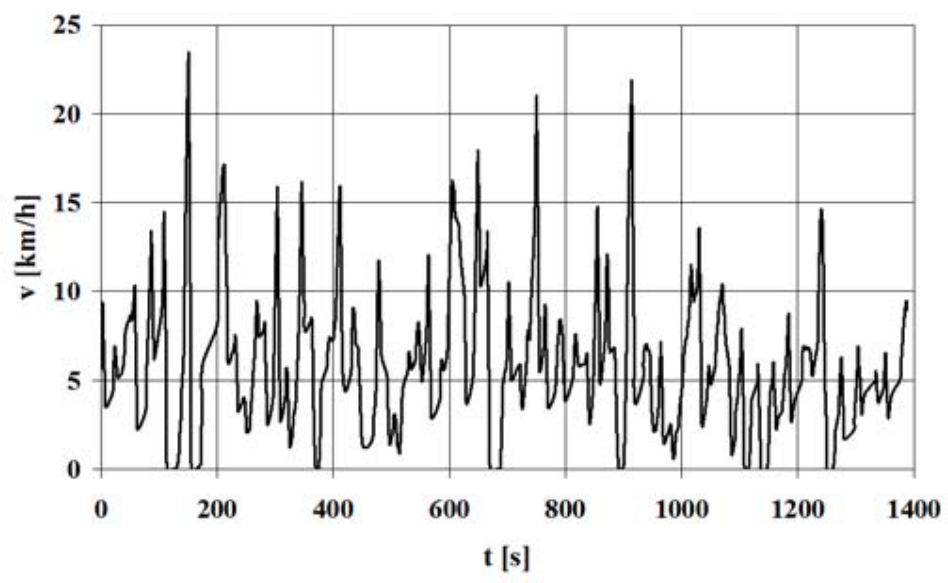

Rys. 5. Realizacja testu Stop and Go 


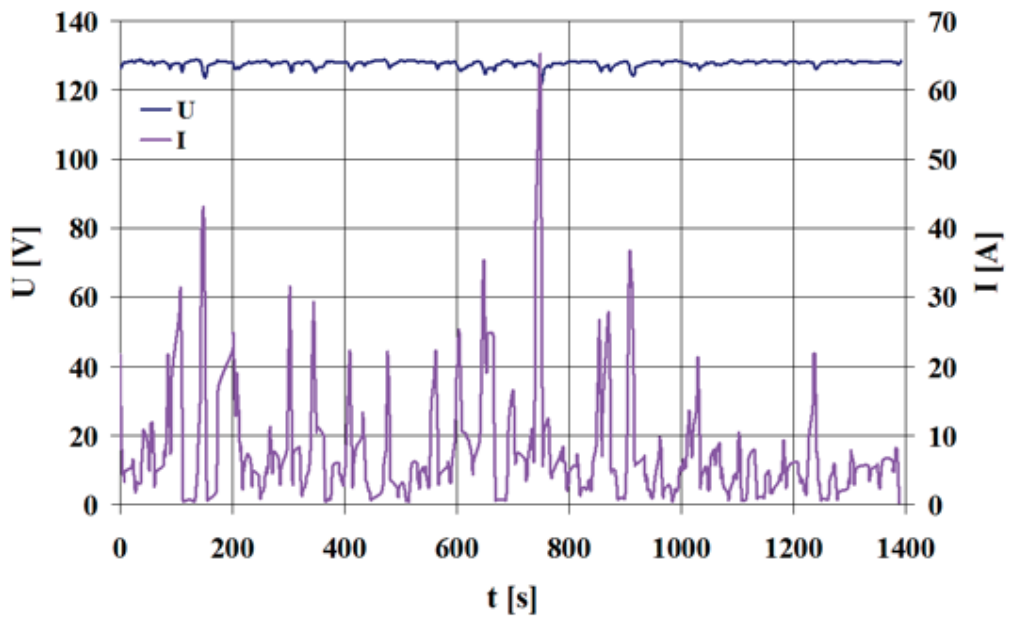

Rys. 6. Natężenie prądu pobieranego z akumulatora i napięcie na zaciskach akumulatora w teście Stop and Go

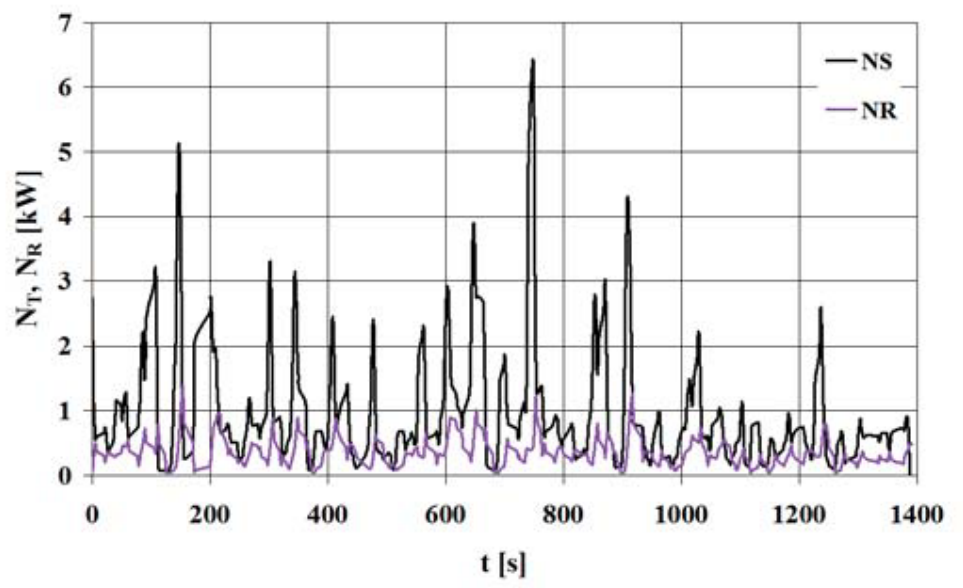

Rys. 7. Moc elektryczna napędu samochodu i moc oporów w teście Stop and Go

Dla testów badawczych wyznaczono sprawność ogólną pojazdu. Problemem było przyjęcie sprawności ładowania akumulatorów. Literatura podaje wartości sprawności ładowania akumulatorów znacznie różniące się wartością w zależności od rodzaju akumulatorów. Przykładowo w publikacji [8] jest przyjmowana wartość sprawności ładowania akumulatorów równa 0,86. W badaniach [4] uzyskano dla akumulatorów kwasowo-ołowiowych znacznie mniejsze wartości, nawet rzędu 0,6. Ostatecznie do analiz w niniejszej pracy przyjęto sprawność ładowania akumulatorów równą 0,65.

Na rysunku 8 zestawiono sprawność ogólną pojazdu w poszczególnych testach.

Sprawność ogólna pojazdu w testach homologacyjnych ma podobną wartość. Znacznie mniejsza jest sprawność ogólna w teście Stop and Go. Test ten charakteryzuje się częstym 


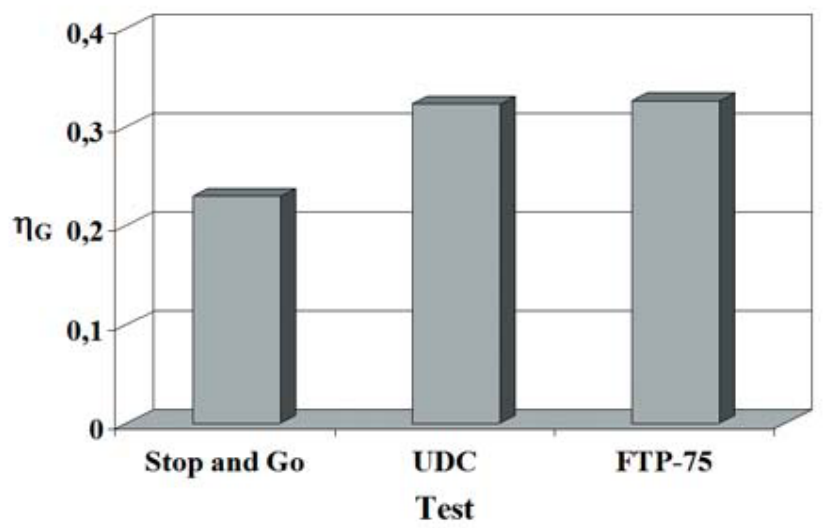

Rys. 8. Sprawność ogólna w testach Stop and Go, UDC i FTP-75

przyspieszaniem i hamowaniem, prędkość średnia pojazdu wynosi 5,8 km/h. W związku z tym można spodziewać się dużych strat. Przypadek taki występuje również w samochodach napędzanych silnikami spalinowymi $[2,5]$.

Na rysunku 9 przedstawiono średnie drogowe zużycie energii.

Średnie drogowe zużycie energii ma podobną wartość dla testów FTP-75 i Stop and Go, mniejsza wartość jest natomiast dla testu UDC. Jest to prawdopodobnie związane $z$ właściwościami dynamicznymi procesów prędkości w zastosowanych testach. Testy FTP-75 i Stop and Go charakteryzują się silniejszymi właściwościami dynamicznymi niż test UDC. Jest to widoczne m.in. we właściwościach częstotliwościowych - większa jest wartość widmowej gęstości mocy prędkości w testach FTP-75 i Stop nad Go w stosunku do testu UDC dla dużych częstotliwości [5]. Właściwość ta wynika ze sposobu wyznaczania

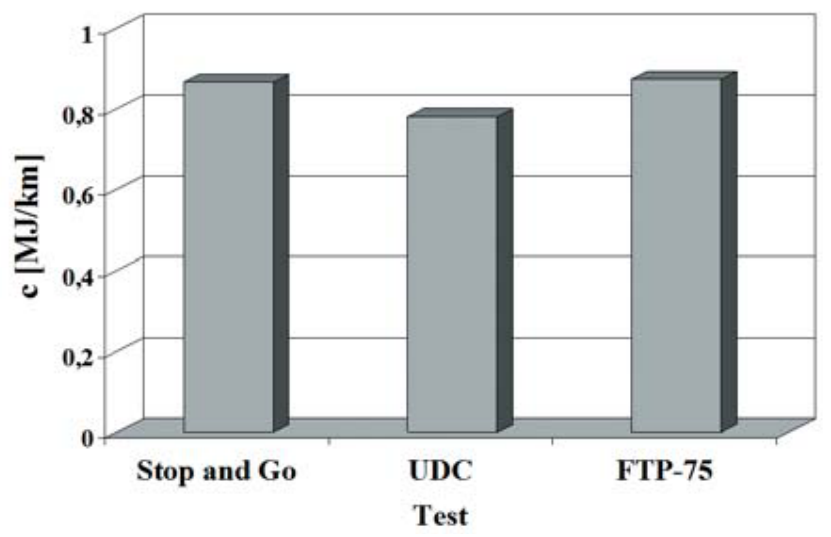

Rys. 9. Średnie drogowe zużycie energii w testach Stop and Go, UDC i FTP-75 
analizowanych testów, mianowicie testy FTP-75 Stop and Go są stworzone zgodnie z kryterium wiernej symulacji $w$ dziedzinie czasu, a test UDC jest wynikiem syntezy zgodnie z podobieństwem charakterystyk punktowych w warunkach badań i rzeczywistego użytkowania.

Przeprowadzono również badania średniego drogowego zużycia energii w stanach dynamicznych: dodatniego przyspieszenia i ujemnego przyspieszenia. Wyniki tych analiz przedstawiono na rysunkach 10-12.

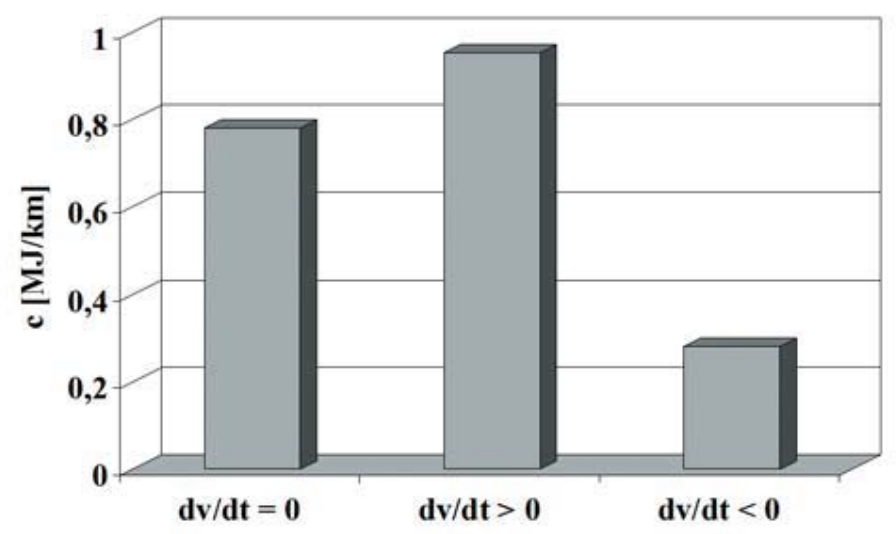

Rys. 10. Średnie drogowe zużycie energii w stanach dynamicznych dodatniego przyspieszenia i ujemnego przyspieszenia w teście UDC

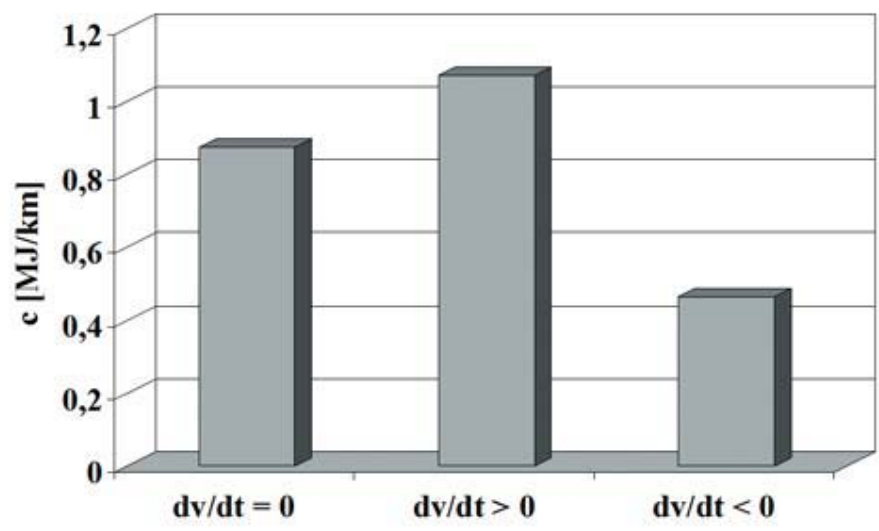

Rys. 11. Średnie drogowe zużycie energii w stanach dynamicznych dodatniego przyspieszenia i ujemnego przyspieszenia w teście FTP-75 


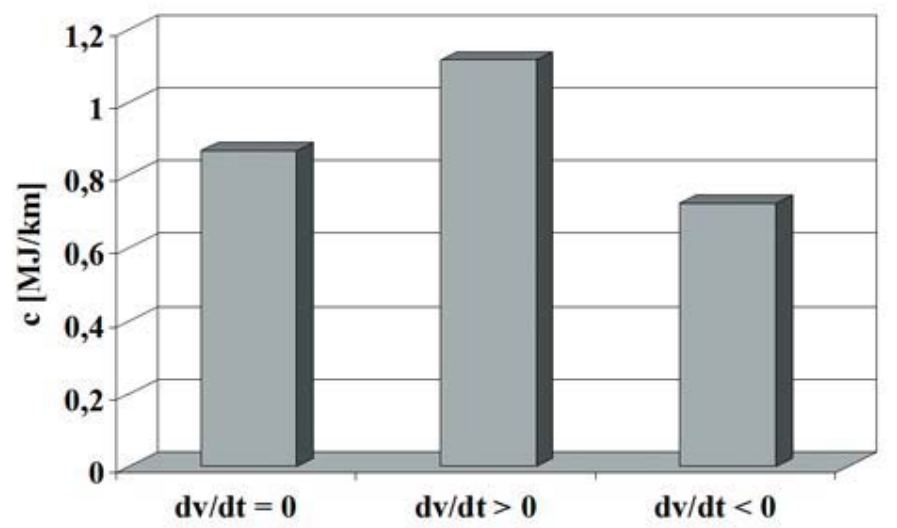

Rys. 12. Średnie drogowe zużycie energii w stanach dynamicznych dodatniego przyspieszenia i ujemnego przyspieszenia w teście Stop and Go

Wyniki analiz są oczekiwane: większe średnie drogowe zużycie energii przypada na fazy przyspieszania. Największa różnica średniego drogowego zużycia energii w rozpatrywanych fazach dynamicznych występuje dla testu UDC.

\section{Podsumowanie}

Obecne priorytety rozwoju napędów elektrycznych w pojazdach mają przede wszystkim charakter ekologiczny. Samochody elektryczne w miejscach użytkowania praktycznie nie emitują zanieczyszczeń ( $w$ rzeczywistości oczywiście emitują cząstki stałe, pochodzące z par trybologicznych w pojeździe, współpracy kół z nawierzchnia jezdną oraz wzniecania pyłów z jezdni). Samochody elektryczne charakteryzują się również mniejszym natężeniem emitowanego hałasu niż ma to miejsce w przypadku pojazdów z silnikami spalinowymi. Ważną zaletą użytkowania samochodów elektrycznych jest możliwość ochrony zasobów surowców do produkcji paliw ciekłych i gazowych. Istnieje wiele rodzajów pierwotnych nośników energii możliwych do wykorzystywania do zasilania samochodów elektrycznych. Wynika to ze stosowanej technologii wytwarzania energii elektrycznej. Obecnie - przynajmniej w Polsce - energia elektryczna jest wytwarzana przede wszystkim z węgla kamiennego, ale jest możliwe wykorzystanie energii odnawialnej, a także techniki nuklearnej, szczególnie w przyszłości energii syntezy jądrowej. Obecne analizy szkodliwości pojazdów elektrycznych dla środowiska w cyklu Well-to-Whell uwzględniają znaczne obciążenie środowiska, związane z wytwarzaniem energii elektrycznej. Trudno jest, w związku z tym, obiektywnie ocenić ekologiczne skutki tzw. elektryfikacji transportu drogowego. Wskaźniki syntetyczne obciążenia środowiska przez motoryzację, wyznaczane w analizach cyklu istnienia obiektu (ang. LCA - Life Cycle Assessment), są silnie zależne nie tylko od zastosowanych rozwiązań technicznych i organizacyjnych (w szczególności technologii przetwarzania nośników energii), ale i od przyjętej metodyki analizy LCA. Dodatkowo znaczna względność i - w konsekwencji - pewnego rodzaju dowolność 
prowadzenia tych analiz powodują możliwość wręcz manipulacji w związku z silnymi naciskami grup zaangażowanych materialnie i emocjonalnie w rozwój porównywanych rozwiązań technicznych - w tym przypadku transportu klasycznego, opartego na spalaniu paliw ropopochodnych, i elektrycznego. Z tych powodów porównywanie występujących w literaturze wartości wskaźników charakteryzujących obciążenie środowiska przez motoryzację dla różnych rozwiązań technicznych może się okazać mało użyteczne.

Badania zużycia energii przez samochody elektryczne są wykonywane najczęściej w warunkach homologacyjnych. W niniejszej pracy badania takie uzupełniono warunkami testu specjalnego Stop and Go, symulującego jazdę w zatorach ulicznych. Wyniki badań wykazały małą wrażliwość drogowego zużycia energii na model ruchu pojazdu, jednocześnie sprawność ogólna pojazdu okazała się wrażliwa na model ruchu. Potwierdziła się wrażliwość drogowego zużycia paliwa na występowanie stanów dynamicznych: we wszystkich przypadkach większe średnie drogowe zużycie energii przypada na fazy przyspieszania.

Zaproponowana procedura badań zużycia energii na hamowni podwoziowej okazała się skuteczna. Celowe jest zweryfikowanie wyników badań w warunkach rzeczywistego użytkowania pojazdu w ruchu w mieście - badania takie są obecnie wykonywane.

\section{Literatura}

[1] BECKER T.A., SIDHU I., TENDERICH B.: Electric vehicles in the United States. A New model with forecasts to 2030. Center for Entrepreneurship \& Technology (CET). Technical Brief Number 2009.1.v.2.0. Revision Date: August 24, 2009.

[2] BUWAL, INFRAS AG: Luftschadstoffemissionen des Strassenverkehrs 1950 - 2010. BUWAL-Bericht Nr. 255. 1995.

[3] CHERRY C.: Electric two-wheelers in China: Analysis of environmental, safety, and mobility impacts. Ph.D. Dissertation. University of California, Berkeley 2009.

[4] CHŁOPEK Z. et al.: Badania empiryczne zużycia energii przez samochód elektryczny w warunkach symulujących rzeczywiste użytkowanie. Praca statutowa ITS nr 6110/COŚ. Warszawa 2012.

[5] CHŁOPEK Z.: Modelowanie procesów emisji spalin w warunkach eksploatacji trakcyjnej silników spalinowych. Prace Naukowe. Seria „Mechanika" z. 173. Oficyna Wydawnicza Politechniki Warszawskiej. Warszawa 1999.

[6] CHŁOPEK Z.: Ochrona środowiska naturalnego. Pojazdy samochodowe. WKŁ. Warszawa 2002.EAVES S., EAVES J.: A cost comparison of fuel-cell and battery electric vehicles. http://65.181.169.214/docs/bev_vs_fcv_compare_acp.pdf.

[8] EBERHARD M., TARPENNING M.: The $21^{\text {st }}$ century electric car. Tesla Motors Inc. 6 October 2006.

[9] Electric and hybrid vehicle research, development and demonstration program. Petroleum-equivalent fuel economy calculation. Final Rule. 10 CFR Part 474. United States Department of Energy, Federal Register 64. 2011-01-01.

[10] Exploring electric vehicle. Adoption in New York City. January 2010. http://www.nyc.gov/html/om/pdf/2010/ pr10_nyc_electric_vehicle_adoption_study.pdf

[11] HIROTA T.: Nissan's electric and hybrid electric vehicle program. SAE Hybrid Vehicle Symposium. San Diego CA, 13-14 February 2008.

[12] KROMER M.A.; HEYWOOD J.B.: Electric powertrains: Opportunities and challenges in the U.S. light-duty vehicle fleet. Publication No. LFEE 2007-03 RP.

[13] MATTHEW-WILSON C.: A critique of the economic and environmental value of electric cars. C. Matthew-Wilson, 2010.

[14] MERKISZ ]., PIELECHA I.: Alternatywne napędy pojazdów. Wydawnictwo Politechniki Poznańskiej. Poznań 2006. 
[15] NÚÑEZ P. J. M. et al.: Electric vehicle. A cyclical story of death and resurrection. International Conference on Renewable Energies and Power Quality (ICREPQ'10) Granada (Spain), 23th to 25th March, 2010.

[16] RAUT A. K.: Role of electric vehicles in reducing air pollution: a case of Katmandu, Nepal. The Clean Air Initiative. http://www.cleanairnet.org/baq2003/1496/articles-58076_resource_1.doc. 2011.

[17] RIDLAY R.: The future of the electric car. Ridley Engineering Inc. 2006. http://www.apec-conf.org/2006/ APEC_2006_Plenary_3.pdf.

[18] SAVITZKY A., GOLAY M.J.E.: Smoothing and differentiation of data by simplified least squares procedures. Analytical Chemistry. 1964. 36: 1627-1639.

[19] SZUMANOWSKI A.: Pojazdy ekologiczne - przyszłość samochodów hybrydowych. Przegląd Mechaniczny $1 / 2010$.

[20]van ESSEN H., KAMPMAN B.: Impacts of electric vehicles - Summary report. Publication number: 11.4058.26. Delft, April 2011. www.cedelft.eu.

[21] van HAAREN R.: Assessment of electric cars' range requirements and usage patterns based on driving behavior recorded in the National Household Travel Survey of 2009. Study of the Solar Journey USA. Earth and Environmental Engineering Department, Columbia University, Fu Foundation School of Engineering and Applied Science. New York. December, 2011.

[22] WAKEFIELD E.H.: History of the electric automobile: Batery-only powered cars. Warrendale PA. SAE 1994.

[23]WEINERT J.X. et al: The future of electric two-wheelers and electric vehicles in China. eScholarship. Series: Recent Work. University of California. 05-01-2008. http://escholarship.org/uc/item/0d05f8v9.

[24] WEINERT J., MA C., CHERRY C.: The transition to electric bikes in China: history and key reasons for rapid growth. Transportation 34. 2007. 301-318.

[25]WESTBROOK M.H.: The electric car: Development and future of battery, hybrid and fuel-cell cars. IEE Power \& Energy Series, 38. 2001.

[26] Wheel to Well Analysis of EVs. MIT Electric Vehicle Team. MIT. April 2008. http://web.mit.edu/evt/summary_ wtw.pdf.

[27] Worldwide emission standards. Passenger cars and light duty vehicles. Delphi. Innova-tion for the real world. 2011/2012. 